\title{
UPAYA KOMUNIKASI PEMASARAN SENI LUKIS KALIGRAFI DI DESA CIRANJANG CIANJUR
}

\author{
${ }^{1)}$ Lulu Ulfa Sholihannisa, ${ }^{2)}$ Hadiansyah Ma'sum, ${ }^{3)}$ Andri Nurmansyah \\ ${ }^{1)}$ Program Studi D3 Manajemen Informatika \\ ${ }^{2)}$ Program Studi D3 Manajemen Informatika \\ ${ }^{3)}$ Program Studi D3 Administrasi Bisnis \\ Politeknik LP3I Bandung \\ Jl. Pahlawan No. 59 Bandung, Jawa Barat, Indonesia \\ Email: luluulfasholihannisa@plb.ac.id
}

\begin{abstract}
ABSTRAK
Cianjur yang mempunyai beberapa pesantren Islam memberikan pengajaran dan pendidikannya melalui seni kaligrafi Islam, yaitu kaligrafi Arab yang isinya bertuliskan ayat-ayat al-Qur'an. Namun, bukan hanya santri yang bisa memperlajari dan membuat kaligrafi Arab. Di Daerah Ciranjang Kabupaten Cianjur terdapat kelompok pengrajin seni lukis kaligrafi yang sangat indah. Untuk dapat mempromosikan hasil produksi lukisan kaligrafi tersebut, diperlukan upaya-upaya dalam komunikasi pemasaran produk seni lukis kaligrafi di Desa Ciranjang Kabupaten Cianjur ini. Oleh sebab itu, peneliti melakukan penelitian di Desa Ciranjang, Kabupaten Cianjur dengan tujuan untuk mengetahui proses produksi seni lukis kaligrafi, serta untuck mengetahui upaya apa saja yang dilakukan komunikasi pemasaran seni lukis kaligrafi?. Metode yang dilakukan adalah studi kasus dengan pendekatan kualitatif, dengan tahapan penelitian observasi, wawancara, dan reduksi data. Berdasarkan hasil pembahasan penelitian dijelaskan bahwa proses produksi dilakukan dengan menggunakan media triplek dan beberapa alat yang dipergunakan seperti cat, palet, dan lain sebagainya. Upaya komunikasi yang dilakukan adalah dengan menggunakan personal selling dan marketing even.
\end{abstract}

Kata Kunci: komunikasi pemasaran, kaligrafi, market place 


\section{PENDAHULUAN}

Kaligrafi merupakan bentuk seni dalam menulis maupun tulisan. Dibeberapa negara mempunyai kekhasan nya masing-masing. Bangsa Arab telah terlebih dahulu memperkenalkan seni kaligrafi Arab untuk kebutuhan menulis sya'ir atau puisi sebelum turunnya al-Qur'an. Hal ini yang menjadikan pesatnya perkembangan kaligrafi Arab sampai sekarang.

Kaligrafi merupakan suatu ornamen teks arab yang lebih banyak diambil dari isi ayat-ayat al-Qur'an maupun kalimat-kalimat tauhid. Hal tersebut diperkuat oleh Huda dan Muharsafa (2010:36) yang menjelaskan bahwa "kaligrafi Islam disebut dengan the art of Islamic art (seninya seni Islam)”. Sedangkan akar kaligrafi adalah hieroglif Mesir (kanaan, Semit) lalu terpecah menjadi khat Efiqi (Fenesie) yang terpecah lagi menjadi Arami (Aram) dan Musnad (kitab yang memuat segala macam hadits). "Kaligrafi arab yang bersumber pada al-Qur'an selain memiliki bentuk yang artistik juga memiliki makna yang luhur yang merupakan penggambaran firman Allah SW" (Rispul, 2012: 11).

Apabila menggali sejarah Islam, perkembangan kaligrafi mulai dari zaman pra-Islam masyarakat arab saat itu tidak menyukai dunia tulis menulis, mereka lebih senang menghafal daripada menulis. Baru setelah Nabi Muhammad diangkat sebagai Nabi dan Rasul perkembangan tulis menulis berkembang sampai zaman Khulafaul Rasyidin salah satunya melalui kaligrafi Islam yang salah satu fungsinya adalah untuk membukukan al-Qur'an dan as-Sunnah. Kaligrafi sebagai seni dapat dihasilkan dengan mengikuti "empat mekanisme kehidupan yaitu api, air, angin, dan udara" (Huda dan Muharsafa, 2010: 36). Kaligrafi mempunyai gara-gaya yang sangat indah dan unik. Sirojuddin (2014: 226) menjelaskan bahwa gaya-gaya penulisan seni kaligrafi terdiri dari "kontemporer tradisional, kontemporer figural, kontemporer simbolik, kontemporer ekspresionis, dan kontemporer abstrak".

Kaligrafinya pada umumnya dipelajari di berbagai pondok pesantren. Baik itu pondok pesantren salafi maupun pondok pesantren modern. Pondok pesantren modern merupakan salah satu bentuk pesantren yang ada di Indonesia. Sesuai data statistik Direktorat Pendidikan Pondok Pesantren Kementrian Agama (ditpontren Kemenag), perkembangan pesantren di pulau Jawa tahun 2016 yang dilansir Education Management Information System atau Pangkalan Data EMIS pondok 
pesantren mengaji (salafi) berjumah kurang lebih 5.994 pesantren salafi, sedangkan untuk pondok pesantren modern berjumlah kurang lebih 3.173, jadi total pesantren di Jawa Barat \pm 9.167 Pondok Pesantren. Jawa Barat merupakan daerah yang mempunyai pendidikan pesantren terbanyak dibandingkan provinsi lainya di Indonesia. Begitupun perkembangan pesantren di Cianjur sangat pesat, mulai dari pesantren salafi (tradisional), Pesantren Modern, dan SMA IT berbasis Pesantren.

Mengadopsi dari pendidikan di pesantren, yang terdiri dari berbagai macam bidang keilmuan, masyarakat cianjur tertarik untuk menyekolahkan anak-anaknya ke beberapa pesantren di daerah cianjur. Banyak lulusan pesantrennya yang menjadi guru-guru mengaji di lingkungan masyarakat serta profesi lainnya.

Selain bidang keagamaan, beberapa pesantren di cianjur banyak yang mengajarkan beberapa kesenian kaligrafi sebagai mata pelajaran khusus di pesantren, selain diajarkan di dalam kelas yang termasuk kedalam kurikulum, kesenian kaligrafi juga dipelajari khusus sebagai ekstrakulikuler sekolah. Dari pengalaman-pengalaman tersebut, diajarkan kembali kebebarapa anggota masyararakat sehingga masyarakat data belajar seni kaligrafi mulai dari khat-khat (tulisan arab) sampe seni kaligrafi yang sangat bervariatif dan indah.

Pada umumnya kesenian kaligrafi memang dibutuhkan bakat desain atau seni yang dimiliki oleh pengrajin atau orang yang menguasasi seni kaligrafi, tidak semua orang bahkan pe sekalipun bisa membuat kaligrafi. Karena dalam pembuatannya terdapat keahlian-keahlian atau pakem-pakem tertentu dalam membuatnya.

Penelitian dalam pengembangan kapasitas masyarakat dalam bidang seni kaligrafi sebelumnya pernah dilakukan oleh Ikhwan, dkk., di RW 04 desa Cipacing, Jatinangor, Sumedang, Jawa Barat. Penelitian tersebut, dialkukan dengan cara memeberikan penyuluhan dan pelatihan kaligrafi. Penyuluhan dan pelatihan tersebut berisi mengenai pengenalan alat dan perlengkapan kaligrafi, alat peraga, serta modul pelatihan. (Ikhwan, dkk., 2017).

Tepat di Desa Ciranjang, terdapat potensi masyarakat dalam bidang Ekonomi Kreatif yaitu kerajinan Kaligrafi. Bisnis ini dijalankan masih secara manual karena masih menggunakan alat-alat yang sederhana dalam pembuatannya, sedangkan pada saat ini dibeberapa kota besar sudah banyak pengrajin seni kaligrafi 
yang sudah mempergunakan dan memanfaatkan kemajuan teknologi dalam pembuatan seni kaligrafi, baik dari media, bahan, penggunaan cat dan lain sebagainya. Bahkan dari segi penjualannya pun hanya beberapa pengrajin saja yang mempromosikan produknya dengan memanfaatkan teknologi informasi seperti media social ataupun toko online (market place).

Dengan demikian fokus permasalahan dalam penelitian ini adalah 1) bagaimana proses produksi seni lukis kaligrafi?; 2) upaya apa saja yang dilakukan dalam komunikasi pemasaran seni lukis kaligrafi di Desa Ciranjang, Cianjur? Tujuan dari penelitian ini adalah untuk mengetahui 1) proses produksi seni lukis kaligrafi; dan 2) upaya yang dilakukan dalam komunikasi pemasaran seni lukis kaligrafi di Desa Ciranjang, Cianjur.

\section{KAJIAN PUSTAKA}

\section{Sejarah Kaligrafi}

Kaligrafi yang merupakan bentuk karya seni dalam menulis, mempunyai beragam bentuk kekhususan dalam tulisan. Kaligrafi pada beberapa negara mempunyai nama dan kaidah masing-masing dalam menulis dengan menggunakan seni karya kaligrafi. Di Jepang terdapat seni kaligrafi Jepang yang disebut dengan “Shodo", "Seoye di korea, dan di China disebut dengan "Shufa/Yi-shu”. Sedangkan seni tulis arab sering disebut "Khat" (Sabikin, 2017:159). Jika Shodo memperlihatkan keindahan seninya melalui kaligrafi kanji yang indah, maka kaligrafi Arab memberikan keindahannya dari aya-ayat pada kitab suci Al-Qur'an.

Apabila merunut pada asal usul kaligrafi, yaitu berasal dari bahasa Inggris Calligraphy, istilah ini juga berasal dari bahasa Latin Kallos yang berarti indah, dan Graph berarti tulisan atau aksara. Jadi arti seutuhnya kaligrapi adalah kepandaian menulis elok/indah atau tulisan elok/indah.

Pertumbuhan dan perkembangan kaligrafi Arab semakin pesat, pembelajarannya tidak hanya diberikan kepada santri-santri pondok pesantren saja, namun dikalangan masyarakat pun telah banyak berkembang seiring dengan perkembangan seni lukis pada umumnya. Pada zaman sekarang, kita dapat menemukan dua jenis Khat atau kaligrafi Arab, yaitu seni lukis kaligrafi Arab dan Kaligrafi murni seperti yang kita temukan di dalam setiat kitab al-Qur'an. 
Ditinjau dari segi sejarah, seni kaligrafi lahir dari ide menggambar atau lukisan yang dipahat atau dicoretkan dalam benda-benda tertentu, seperti daundaun kulit kayu, tanah dan batu. Akar dari tulisan Arab itu dari Mesir yaitu meliputi daerah Kan'an, Semit, atau Turnesia (sekarang adalah wilayah Libanon dan Laut Tengah), dari tulisan Hierogrhaph. Lalu tulisan tersebut terpecah menjadi khat Feniqi (Funisia), dengan cabang-cabang tulisan Arami: Nabathi di Hirah atau Hurun, Sataranjih-Suryani di Irak dan Musnad: Safawi, Samudi, Lihyani (Utara Jazirah Arab) dan Humeri (Yulika, 2016: 224). Dengan demikian tulisan yang benar-benar digunakan oleh masyarakat Arab adalah tulisan Nabathi dan Musnad.

Apabila melihat pada persepektif antropologi dan sosiologis perilaku masyarakat Arab (pra Islam), suku bangsa Arab dikenal sebagai suku yang nomaden, hidup bersuku-suku dengan fanatisme yang sangat tinggi sedangkan sikap dan rasa toleransi nya sangat rendah. Selain itu, karena belum adanya budaya tulis-menulis, menyebabkan segala bentuk aktivitas komunikasi dan aktivitas lainnya hanya berupa mulut ke mulut. Sarif (2016) mengemukakan bahwa pesatnya perkembangan kaligrafi disebabkan oleh tiga faktor, yaitu berdasarkan motivasi normative, penulisan al-Qur'an, dan bahasa Arab sebagai bahasa al-Qur'an. Motivasi normative adalah semangat yang dimunculkan ayat-ayat al-Qur'an yang berupa norma-norma yang memiliki daya pengaruh terhadap kesadaran dan tingkah laku umat Islam dalam hubungannya dengan tulis menulis yang kemudian mempengaruhi kemajuan kaligrafi.

Khat kaligrafi terdiri dari beberapa jenis, yaitu khat kufi yang menjadi dasar dalam penulisan al-Qur'an dengan gaya yang belum terdapat syakal (menetapkan harakat huruf-huruf) maupun I'jam (tanda baca). Pada periode akhir pemerintah Bani Umayah (661 - 705 M) hingga pertengahan kekuasaan Bani Abbasiyah di Baghdad, yaitu pada khalifah al-Makmun ditemukan enam pokok kaidah khat atau yang sering disebut dengan istilah Al-Aqlaam as-Sittah enam tulisan pokok anatara lain Tsuluts, Naskh, Muhaqqaq, Raihaaniy, Riq'iy atau Riq'ah, dan Tauqii (Huda, 2017: 289). 


\section{Pemasaran}

Pemasaran merupakan suatu bentuk interaksi dalam perniagaan atau perdagangan dengan sasaran yang telah ditentukan yang melibatkan bentuk komunikasi untuk mencapai tujuan pemasaran tertentu. Pemasaran adalah sekumpulan kegiatan dimana perusahaan dan organisasi lainnya melakukan kegiatan pertukaran melalui persetujuan antara mereka dan pelanggannya (Lengkey, dkk., 2014:1).

Menurut Kotler dan Amstrong (2015) dalam Fajrin dan Wibowo (2018: 4), pemasaran adalah proses dimana perusahaan menciptakan nilai bagi pelanggan dan membangun hubungan dengan pelanggan yang kuat untuk menangkap nilai dari konsumen sebagai imbalan.

\section{Komunikasi Pemasaran}

Komunikasi pemasaran adalah kegiatan yang ditujukan untuk memperkenalkan, menjalin maupun menciptakan interaksi antara perusahaan dengan mitra usaha untuk mengkomunikasikan perusahaan, produk maupun jasa kepada pihak luar baik mitra usaha, siplier maupun konsumen. Nickels (1984) menyebutkan komunikasi pemasaran merupakan pertukaran informasi dua arah dan persuasi yang memungkinkan proses pemasaran berfungsi lebih efektif dan efisien. DeLozier (1966), komunikasi pemasaran adalah dialog yang berkesinambungan antara para pembeli dan penjual dalam suatu arena pasar (Kusniadji, 2016: 83).

\section{METODE PENELITIAN}

Pendekatan penelitian dilakukan dengan cara pendekatan kualitatif. Adapun metode yang digunakan adalah studi kasus. Metode ini dilakukan untuk mencari tau atau menggali suatu kasus untuk memperoleh gambaran secara menyeluruh dan mendalam terhadap upaya proses produksi dan upaya komunikasi pemasaran seni lukis kaligrafi di Desa Ciranjang, Kecamatan Cianjur, Kabupaten Cianjur. Pada penelitian ini, peneliti merupakan instrument utama dalam penelitian. Adapun tahapan penelitian ini adalah sebagai berikut: 
1) Observasi lapangan. Observasi ini dilakukan untuk memperoleh informasi mengenai kegiatan seni lukis kaligrafi yang terdapat di masyarakat RW 18 Desa Ciranjang, Kecamatan Cianjur, Kabupaten Cianjur, Jawa Barat. Pelaksanaan penelitian ini dilaksanakan mulai dari 15 Juli sampai 30 Agustus 2019, atau kurang lebih sekitar 1,5 bulan. Dengan metode ini, diperoleh data berupa keadaan masyarakat pengrajin seni kaligrafi, metode pembuatan kaligrafi, media pembuatan kaligrafi, dan cara memasarkan produk kaligrafi yang sudah jadi. Pengrajin tersebut, kami menyebutnya dengan sebutan "mitra" peneliti.

2) Melakuakn wawancara kepada mitra pengrajin seni lukis kaligrafi dan perangkat desa.

3) Melakukan dokumentasi untuk mengumpulkan data-data yang dibutuhkan dalam penelitian.

4) Mereduksi data yang berfungsi untuk memilih atau memilah data yang relevan dengan masalah penelitian. Kemudian dilakukan penyajian data dan memverifikasi data secara bersamaan lalu ditarik kesimpulan secara utuh.

\section{HASIL DAN PEMBAHASAN}

Pada pelaksanaan penelitian ini, realisasi pelaksanaan sesuai dengan perencanaan awal tim pelaksana. Pada tahap awal, tim melakukan observasi berupa survey ke Desa Ciranjang Kecamatan Cianjur, Kabupaten Cianjur Jawa Barat yang dilaksanakan pada tanggal 23 Juli 2019. Hasil survey yang diperoleh adalah terdapat beberapa pengrajin bentuk usaha masyarakat desa ciranjang yaitu pengrajin kaligrafi terdapat di RW 18, pengrajin kursi dari rotan terdapat di RW 15, kripik pisang terdapat di RW 13, dan bibit ikan patin terdapat di RW 18. Namun, berhubung waktu yang sangat terbatas serta kendala jarak antara kota tim pelaksana dengan daerah pengabdian yang cukup jauh serta keterbatasan-keterbatasan lainnya, maka tim pelaksana memutuskun untuk melakukan penelitian hanya pada upaya komunikasi pemasaran seni lukis kaligrafi. Selain itu juga adalah faktor penyesuaian kepakaran dan kompetensi yang dimiliki oleh tim pelaksana, salah 
satunya yaitu kompetensi yang dimiliki oleh salah satu tim pelaksana dalam bidang kaligrafi. 
Gambar 1. Kegiatan Observasi dan Wawancara di Lapangan

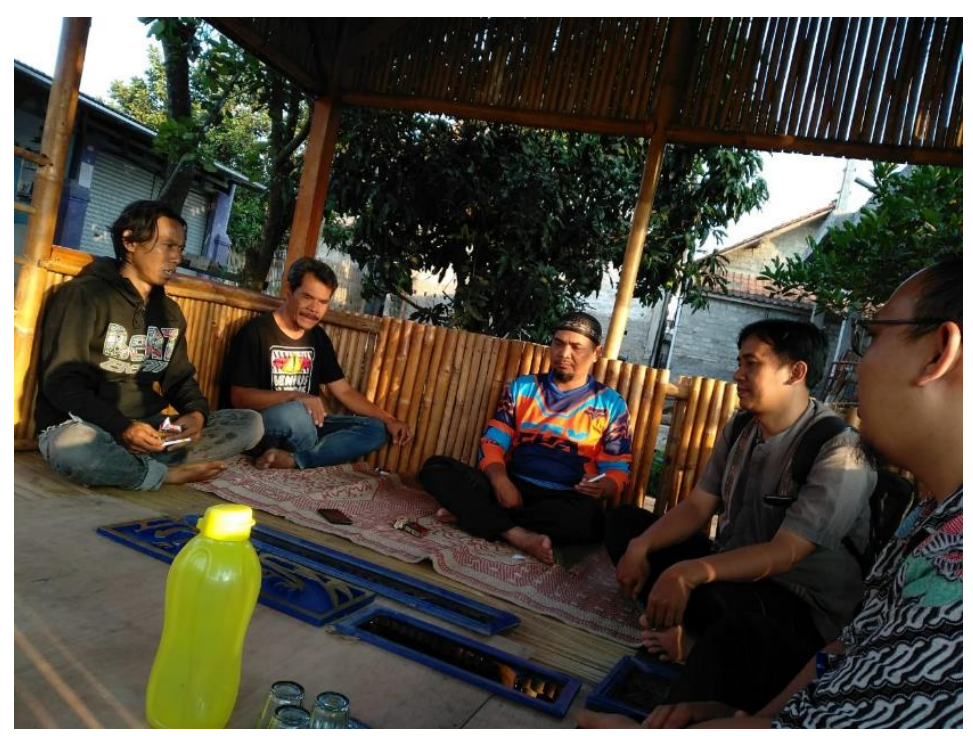

\section{Produk lukisan kaligrafi}

Dari termuan dilapangan, produk lukisan kaligrafi yang dibuat oleh mitra dibuat dengan memanfaatkan media atau bahan baku teriplek bekas, kaca, alat lukis (koas, piring tinta/palet, cat), gergaji, cutter s penggaris, meteran kayu, pilok semprot, pensil, spidol, dan amplas. Teriplek bekas diambil sebagai bahan baku utama karena untuk meminimalisir cost bahan dasar untuk memproduksi lukisan kaligrafi.

Mitra menerima triplek bekas dari beberapa supplier sisa bahan bangunan ataupun dari tukang kayu baik yang terdapat di sekitar daerah desa ciranjang dalam satu kecamatan cianjur ataupun dari daerah-daerah perbatasan kecamatan cianjur. Sehingga mitra tidak harus untuk membeli triplek utuh dari toko-toko bahan bangunan. Dalam pembuatan seni lukis kaligrafi di daerah ciranjang tersebut, mitra tidak mempergunakan bahan kanfas, karena mengingat bahan kanfas cukup sulit diperoleh atau sedikit toko yang menjual kanfas, kendatipun ada toko-toko yang menjual kanfas tersebut, harganya tidak cukup terjangkau mengingat bangsa pasar seni lukis kaligrafi tersebut masih disekitaran daerah cianjur saja. 
Sebagai langkah awal dalam pembuatan, mitra mensortir triplek yang masih bisa digunakan untuk dibuatkan pola diatas triplek tersebut. Apabila terdapat triplek yang tidak bias digunakan atau triplek-triplek tersebut berukuran kecil, mitra mempergunakan triplek-triplek tersebut hanya untuk bahan bakar kebutuhan dapur. Hanya triplek berukuran sedang atau lebar saja yang mitra gunakan untuk menjadi bahan dasar atau media seni lukis kaligrafi.

Setelah melakukan penyortiran triplek, mitra mulai membuat pola pada triplek tersebut dengan menggunakan pensil dan spidol. Pola yang dibuat masih sangat jauh dari kaidah-kaidah penulisan kaligrafi Arab. Namun, dengan adanya media social dan internet, memudahkan mitra untuk belajar menggali keilmuan tentang cara penulisan dan pembuatan seni lukis kaligrafi Arab.

Langkah berikutnya, mitra menyesuaikan warna yang diinginkan dalam pembuatan seni lukis kaligrafi. Berhubung media yang digunakan adalah triplek, maka tidak banyak warna yang dibutuhkan oleh mitra. Mitra menjelaskan bahwa memang media triplek ini, lebih sulit untuk membuat gradasi warna dalam kaligrafi, dikarenakan tekstur media triplek tersebut sangat berbeda dengan kanfas. Triplek lebih cenderung kasar, cat atau tinta yang digunakan pun khusus untuk cat kayu dan tidak mempergunakan cat air seperti pada kanfas. Oleh karena itu, sebelum membuat pola kaligrafi, triplek tersebut harus diamplas terlebih dahulu sampai benar-benar terasa halus. Apabila sudah selesai pengamplasan, barulah mitra dapat membuat berbagai pola yang dinginkan.

Agar mempunyai hasil yang maksimal, mitra melakukan penjemuran pada lukisan-lukisan kaligrafi yang sudah selesai dilukis. Penjemuran tidak membutuhkan waktu lama, hanya satu hari saja dibutuhkan waktu untuk menjemur dibawah terik mata hari yang cukup. Apabila dirasa telah kering, dan warna akhirnya terlihat mengkilat jika diarahkan pada cahaya, maka untuk finishingnya adalah dengan memberikan bingkai serta kaca pada bagian atas lukisan, dan juga kait dibelakang triplek atau pada bingkai, supaya lukisan tersebut dapat dipajang di dinding para konsumen atau pembeli lukisan kaligrafi tersebut.

Sebagai hasil akhir, berikut contoh-contoh kaligrafi yang dihasilkan oleh mitra: 
Gambar 2. Lukisan Kaligrafi
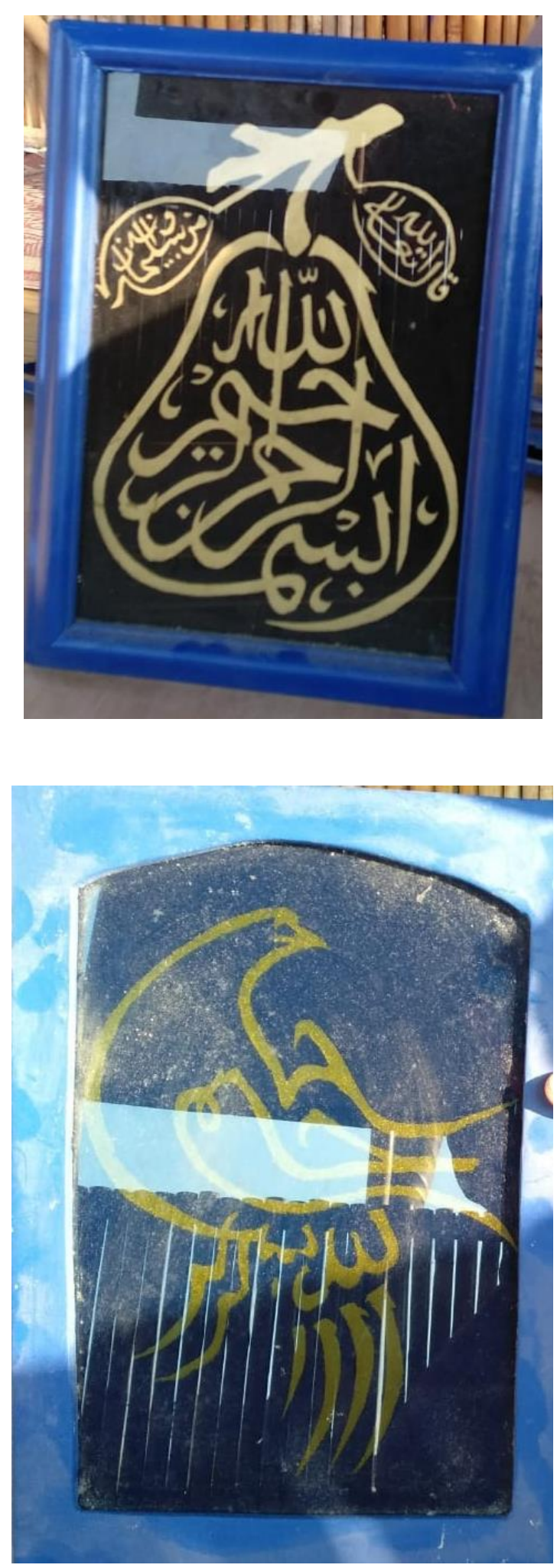

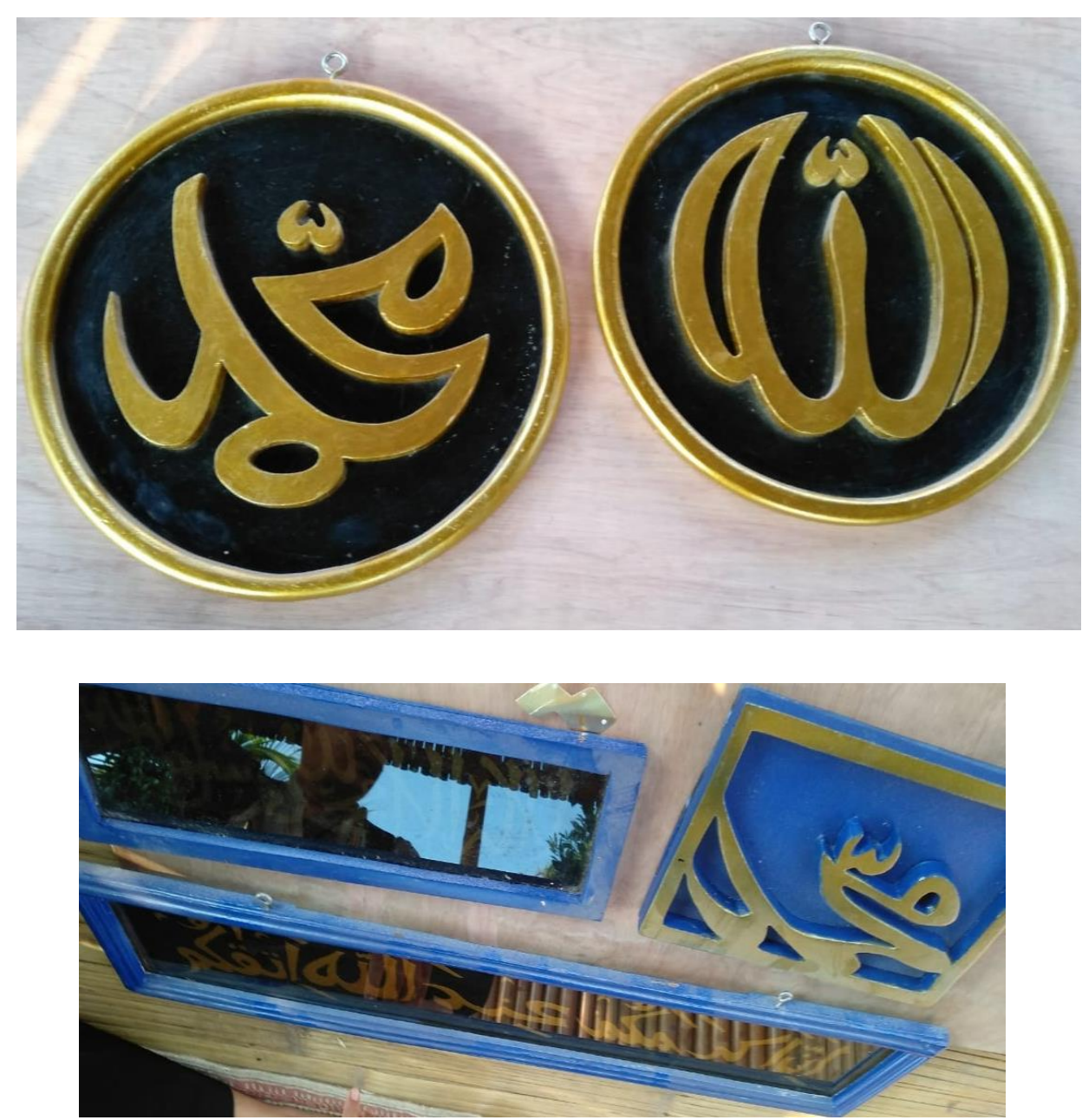

\section{Komunikasi Pemasaran Mitra}

Komunikasi pemasaran pada umumnya digunakan oleh perusahaanperusahaan yang dalam mendistrubusikan produk dari perusahaan tertentu pada sasaran pasar. komunikasi pemasaran ini sudah terbukti keberhasilannya pada beberapa perusahaan besar di Indonesia. Sebagai contoh, kita dapat melihat iklaniklan pada televisi-telivisi nasional seperti iklan produk mie instan, rokok, dan lain sebagainya. Iklan yang dilakukan oleh perusahaan-perusahaan tersebut merujuk pada empat elemen dasar komunikasi pemasaran, yaitu relasi public, iklan, promosi penjualan, dan penjualan personal (Tuckwell: 2008).

Komunikasi pemasaran yang dilakukan oleh mitra seni lukis kaligrafi adalah melalui personal selling. Personal selling merupakan suatu kegiatan promosi atau memperkenalkan suatu produk untuk menarik konsumen terhadap 
produk yang ditawarkan pada konsumen secara langsung atau tatap muka. Personal selling yang merupakan bagian dari marketing communication mix, melakukan promosinya melalui lisan kepada calon pembeli baik perorangan maupun lebih atau kelompok.

Mitra seni lukis kaligrafi melakukan bentuk komunikasi pemasaran personal selling ini, mengingat langkah ini lebih mudah dilakukan kapan pun, dimana pun, dan pada siapapun yang ditemui secara langsung kepada calon pembeli. Selain itu juga karena bangsa pasar dari seni lukis kaligrafi ini lebih dominan adalah masyarakat setempat atau wilayah kabupaten cianjur. Adapun tahapan personal selling yang dilakukan oleh mitra adalah sebagai berikut:

1. Memberikan perhatian. Maksudnya adalah menempatkan pembeli untuk memberikan perhatian nya dengan cara menyapa dan memberikan salam pada calon pembeli, kemudian menjabat tangannya dengan hangat, berusaha untuk selalu memberikan senyuman baik saat calon pembeli bertanya tentang produk lukisan kaligrafi ataupun saat mitra menjelaskan atau menjawab atas pertanyaan-pertanyaan yang diajukan oleh calon pembeli. Apabila dirasakan calon pembeli itu memberikan respon yang dapat membangkitkan emosi, maka mitra sendiri berusaha agar tetap bisa menjaga atau menstabilkan emosi agar konsumen atau calon pembeli tidak merasa tersinggung, sekalipun calon pembeli terlebih dahulu yang memberikan respon tidak baik terhadap mitra.

2. Menarik perhatian. Yang dimaksud dengan menarik perhatian adalah mitra harus mengenali terlebih dahulu perilaku calon pembeli. Mitra akan menjelaskan detail produk kaligrafi mulai dari bahan dasar, proses pembuatan, serta manfaat untuk calon pembeli apabila calon pembeli tersbut membeli produk lukisan kaligrafi dari mitra. Dari situlah akan muncul keinginan calon pembeli akan benar-benar tertarik pada produk lukisan kaligrafi sehingga calon pembeli pun membeli lukisan kaligrafi dari mitra. Pada tahap ini lah terjadinya tindakan dari pengaruh pengaruh komunikasi dua arah yang komunikatif, sehingga calon pembeli terbujuk untuk membeli lukisan kaligrafi. 
Pada kesempatan tertentu, mitra pun melakukan marketing even melalui kegiatan-kegiatan bazar yang diselenggarakan oleh pihak Desa Ciranjang maupun Kabupaten Cianjur. Biasanya marketing even yang dilakukan oleh mitra adalah saat terselenggaranya kegiatan atau acara-acara besar keagamaan, seperti maulid Nabi, Israa Mi'raj, Tabligh Akbar, Milad Santri nasional, ataupun hari libur nasional seperti perayaan 17 Agustus.

Selain kedua macam komunikasi pemasaran, mitra berencana akan melakukan promosi melalui media social dan juga market place yang dapat merambah promosi penjualan lebih jauh dan diharapkan dapat menambah daya jual serta meningkatkan konsumen yang lebih besar lagi.

\section{KESIMPULAN}

Berdasarkan hasil dan pembahasan penelitian diatas, dapat disimpulkan bahwa:

1. Proses produksi seni lukis kaligrafi yang diproduksi oleh mitra adalah bentuk kaligrafi arab yang terbuat dari bahan dasar triplek. Penggunaan triplek bekas bahan bangunan ataupun dari tukang kayu tidak mengurangi keindahan dan hasil produksi lukisan kaligrafi yang di buat oleh mitra pengrajin kaligrafi di Desa Ciranjang, Cianjur.

2. Komunikasi pemasaran yang dilakukan oleh mitra adalah dengan melakukan personal selling dan juga marketing even. Personal selling yang dilakukan oleh mitra adalah dengan cara memberikan dan menarik perhatian calon pembeli sampai calon pembeli tersebut merasa ingin membeli kaligrafi tersebut atas penjelasan yang sangat jelas dari produk lukisan kaligrafi yang diproduksi dan dipromosikan oleh mitra. Marketing even dilakukan sebagai bagian dari marketing communication saat terselenggaranya hari libur/hari besar keagamaan Islam (kecuali Lebaran Idul fitri dan Idul Adha) serta hari libur atau hari besar Negara Kesatuan Republik Indonesia yaitu salah satunya hari Proklamasi Kemerdekaan Indonesia pada tanggal 17 Agustus. 


\section{DAFTAR PUSTAKA}

Abubakar, H. (1991). Sekilas Tentang Asal-Usul Huruf Arab Dan Seni Di Indonesia. Humaniora, 2, 62. Retrieved from https://jurnal.ugm.ac.id/jurnal-humaniora/issue/view/309

Fajrin, F. V. (2018, Mei). Pengaruh Event Marketing Terhadap Brand Image Pada PT Pikiran Rakyat Bandung Tahun 2018. Jurnal Manajemen Pemasaran, 4,4 .

Huda, N. (2017). Implementasi Jenis Khat Naskhi Dalam Pembelajaran Bahasa Arab. Al Mahara Jurnal Pendidikan Bahasa Arab, 3, 289. Retrieved from http://ejournal.uinsuka.ac.id/tarbiyah/index.php/almahara/article/view/174 9

Huda, N. H., \& Muharsafa S. (2010). Asyiknya Belajar Kaligrafi: Cara Praktis Belajar Kaligrafi. Lhoksukon Aceh Utara: Afkari Publishing

Kusniadji, S. (2016, Juli). Strategi Komunikasi Pemasaran Dalam Kegiatan Pemasaran Produk Konsumer Good (Studi Kasus Pada PT Expand Berlian Mulia Di Semarang). Jurnal Komunikasi, 8, 83-98.

Lengkey, L. M. (2014). Peranan Komunikasi Pemasaran Dalam Meningkatkan Pengguna Iklan Di Harian Komentar Manado. Jurnal Acta Diurna, III, 1. Retrieved from https://media.neliti.com/media/publications/90796-IDperanan-komunikasi-pemasaran-dalam-menin.pdf

Murodi, S. (2019). Pandangan Islam Tentang Seni Dan Budaya. Jurnal Pendidikan Konvergensi, VI, 159. Retrieved from https://books.google.co.id/books

Rispul. 2012. Kaligrafi Arab sebagai Karya Seni. Tsaqafa Jurnal Kajian Seni Budaya Islam Vol.1 No. 1 Juni 2012

Sarif, D. (2016). Pengaruh Al-Quran Terhadap Perkembangan Kaligrafi Arab. ETNOHISTORI, III, $170 . \quad$ Retrieved from https://ejournal.unkhair.ac.id/index.php/etnohis/article/view/848

Sirojuddin A.R. 2014. Peta Perkembangan Kaligrafi Islam di Indonesia. Sukabumi: Jurnal al-Turas Vol. XX No. 1 Pesantren Lembaga Kaligrafi Tuckwell. K. J. (2008). Integreted Marketing Communication: Strategic Planning Perspective (Second Edition ed.). USA: Pearso Pretice Hall. 
Yulika, F. (2016). Jejak Seni Dalam Sejaran Islam. Kota Padang Panjang: Institut Seni Indonesia Padang Panjang. 